\title{
MILKRUN ANYAGELLÁTÁSI RENDSZER TERVEZÉSE
}

\author{
Francuz Ádám \\ BSc. hallgató, Miskolci Egyetem, Gépészmérnöki- és Informatikai Kar \\ 3515 Miskolc, Miskolc-Egyetemváros, e-mail: francuzadam13@gmail.com \\ Bányai Tamás \\ egyetemi docens, Miskolci Egyetem, Logisztikai Intézet \\ 3515 Miskolc, Miskolc-Egyetemváros, e-mail: alttamas@uni-miskolc.hu
}

\begin{abstract}
Absztrakt
Az üzemen belüli anyagellátási rendszerek egyik leggyakoribb megvalósitási formája a milkrun, ez különösen igaz az autóipari beszállitói és mechatronikai összeszerelö vállalatokra. A termelési folyamatok hatékonyságát nagymértékben befolyásolja a kapcsolódó logisztikai rendszer hatékonysága. Jelen cikk keretében a szerzök egy olyan tervezési módszert mutatnak be, mely alkalmas milkrun alapú üzemen belüli anyagellátási rendszerek optimális kialakitásának támogatására.
\end{abstract}

Kulcsszavak: üzemen belüli anyagellátás, járattervezés, optimalizálás, modellezés

\section{Abstract}

A wide range of in-plant material supply processes is based on milkrun, especially in the field of automotive industry. The efficiency of logistics and material handling processes has a great impact on the efficiency of the production processes. Within the frame of this article the authors describe a new heuristic approach to design milkrun based in-plant supply.

Keywords: in-plant supply, routing, optimization, modelling

\section{Bevezetés}

A folyamatosan növekvő és diverzifikálódó vásárlói igények miatt lényegesen átalakultak a termelő vállalatok anyagellátási és információs rendszerei. A létrejött célok elérése érdekében napjainkra számos folyamatfejlesztési filozófia, irányzat alakult ki, melyek közül a legismertebb a Lean módszer. A módszer alapjának tekinthető a Toyota Production System (TPS), amely a Toyota Motor Corporation által kidolgozott, az addigi ismeretektől teljesen eltérö termelési módszer. Müködését jól tükrözi, hogy a hidegháború időszakában a japán autóipar termelékenysége lényegesen felülmúlta az amerikai konkurenciát. A TPS módszer folyamatosan fejlődött a XX. század második felében, a tudományos világ az 1970-es években figyelt fel eredményeire, végül az 1990-es években kezdték el alkalmazni az európai és amerikai autóipai vállalatok. Ezt az időpontot tekintik a Lean módszer kezdetének, ugyanis a Lean a TPS európai és amerikai szemléletre formált változata. A Lean a cél, a folyamat, valamint az emberek tiszteletének hármas egységén alapszik. Eredetileg angol szó, jelentése „karcsú”, amely a szemlélet fö céljára is utal: kiszürni minden felesleges mozdulatot és információt a folyamatból, miközben a legnagyobb vevői érték előállítására törekszünk. A szemléletmód a szélsőségeken alapul, amely az autóipari termelö folyamatokban a következőkben jelenik meg:

- maximális érték elóállítása,

- maximális termelékenység,

- minimális idő, energia, erőforrás felhasználásával,

- $\quad$ minimális költségen. 
Jelen kutatás az autóipari vállalatok termelő logisztikájában müködő folyamatait vizsgálja. Fő cél egy olyan idő függvényében optimalizált alapanyagellátó, valamint késztermék gyüjtő Milkrun kocsik útvonalának létrehozása, amely figyelembe tudja venni és reagálni tud a gyakorlatban előforduló esetleges hibákra. A tudományos cikk tartalmazza az általunk kidolgozott módszer matematikai modellezését, illetve annak leírását egy, illetve több milkrun útvonal létrehozása esetén.

\section{A feladat leírása}

Az időparaméter minimalizálása egy olyan metódussal kerül megvalósításra, amelyet egy fiktív gyártócsarnokon segítségével mutatunk be a jobb érthetőség érdekében, valamint így a metódus müködését konkrét számértékekkel tudjuk igazolni. A tényleges anyagmozgatást az autóiparban számos előnye miatt már jól bevált milkrun kocsikkal hajtjuk végre. A gyártócsarnok áll egy raktári kiinduló és érkező pontból, $50 \mathrm{db}$ gyártósorból, 28 db elágazásból, valamint az ezeket összekötő egyenes szakaszokból. A metódus ezeket a szakaszokat választja ki és adja össze úgy, hogy az útvonal minden gyártósort pontosan egyszer érintse, több útvonal esetén pedig egy gyártósort csak egy útvonal érinthessen. A feladat legfontosabb kritériuma, hogy a létrehozott útvonal/útvonalak megtételéhez szükséges idő ne legyen több a milkrun kocsihoz tartozó, különböző okok miatt kialakult időkorlátnál. Ezen felül a létrehozott útvonalak mennyisége nem haladhatja meg a rendelkezésre álló milkrun kocsik számát.

\section{Szakirodalmi áttekintés}

A milkrun rendszerekről szóló szakirodalom az elmúlt években jelentősen megnövekedett. Az egyre összetettebb és dinamikusabb piaci környezet elsajátításában az ipari vállalatok hajlamosak rugalmas gyártási és intralogisztikai folyamatokat megvalósítani, amelyekhez gyakran alkalmazzák a milkrun megoldásokat [1], amit gyakran a Lean módszer részeként említ a szakirodalom [2]. A milkrun hatékonyan biztosítja az anyagellátást a termeléshez, azonban a statikus mennyiségü szállításhoz fontos a kereslet és változásainak pontos ismerete [3]. A számos elképzeléstől és módszertől függetlenül még nem készült általános megoldás a rendszer használatára [4]. A folyamatosan növekvő termékválaszték és a hozzá tartozó keresletingadozás a gyártási logisztika fő kihívása. A milkrun rendszerek dinamikusan tudnak reagálni a változásokra és kezelni tudják azt [5].

A rendszer használatának célja sokszínü, bizonyos kutatásokban a cél a kapacitás kihasználása a szállítási költségek csökkentésével [6], illetve a készletköltségek minimalizálásával [7] párhuzamban. A különböző költségcsökkentéseken túl a rendszer javítja a termelési rendszerek termelékenységét és müködési hatékonyságát [8]. A milkrun rendszerre épülö, üzemen belüli ellátás megtervezése és müködtetése az optimalizálási problémák széles skáláját foglalja magában, mint például a telepítési, járattervezési, ütemezési, hozzárendelési vagy sorban állási problémák [9].

A milkrun megoldásához számos algoritmus, megközelítés köthető, a rendszerek nagyon gyorsan képesek alkalmazkodni a gyártási rendszerek változásaihoz, ezért célszerü megoldás lehet olyan heurisztikus módszerek alkalmazása, mint például az Ant Colony Optimization [10]. A holisztikus megközelítés integrálja a szállítás, tárolás, az időgazdálkodás és az ergonómia elemeit egy olyan modellezési eszközbe, amely megfelel a mai Lean termelési rendszerek követelményeinek [11]. Olyan modellek is rendelkezésre állnak, melyek használatával minimalizálni lehet a rendelési ciklusidőt [12]. A módszer alkalmazhatóságát különböző szimulációs szoftver segítségével lehet vizsgálni. A raktári költségek csökkentésére mikroszimulációs modellt fejlesztettek ki a Simio Simulation szoftverben [13]. A Tecnomatix Plant Simulation vizsgálni tudja a munkahelyek anyagellátását [14]. Ezen szakirodalmi áttekintés után a cikk bemutatja az általunk kidolgozott optimalizálási megoldási módszert egy, illetve több Milkrun kör esetére. 


\section{Matematikai modell}

A modellalkotás során napjaink müszaki gyakorlatában leggyakrabban alkalmazott a matematikai modell. Ennek fö oka a számítástechnika robbanásszerü elterjedése A matematikai modell valamilyen vizsgált rendszerben lejátszódó jelenség, folyamat vagy tevékenység a vizsgálat szempontjából lényeges tulajdonságai közötti összefüggések matematikai megfogalmazása. A modell egyrészt matematikai objektumokból (például számokból, vektorokból) áll, másrészt az objektumok közötti relációkból, amely a matematika szimbólumrendszerén keresztül teremt kapcsolatot a vizsgált rendszer be- és kimenő jellemzői között. [15]

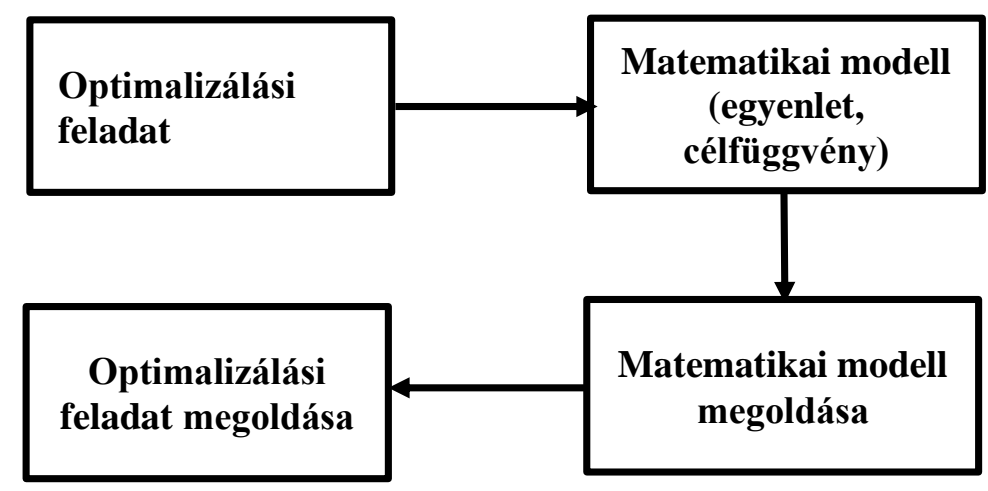

1. ábra. Optimalizálási feladat megoldása matematikai modellezéssel

Az optimalizálási feladat modellezésének első lépése a bemenő paraméterek meghatározása: gyártósorok száma; elágazások száma; objektumok száma; gyártósorazonosító; objektumazonosító; szomszédsági mátrix; objektum távolságmátrix; gyártósor távolságmátrix; Milkrun kocsi tömege, kapacitása. A modellalkotáshoz szükséges megadni a korlátozó feltételeket, amelyek jelen feladatnál az időkorlát, illetve a rendelkezésre álló kocsik száma. A feladat eredménye két paraméterből tevődik össze: a járatszám megadja, hogy hány járattal hajtható végre az anyagmozgatás a korlátozó feltételek figyelembevételével; a bejárási sorrend mátrix tartalmazza az adott járathoz tartozó útvonalat.

Az optimalizálás eredményét a bemenő paraméterekből a korlátozó feltételek betartása mellett a célfüggvény segítségével kaphatjuk meg:

$$
\begin{gathered}
\mathrm{C}(\mathrm{s})=\mathrm{C}_{\mathrm{s}}=\sum_{\mathrm{c}=1}^{\mathrm{x}}\left(\sum_{\mathrm{b}=1}^{\mathrm{m}_{\mathrm{x}}-2} \mathrm{l}_{\mathrm{er}_{\mathrm{c}, \mathrm{b}}, \mathrm{er}_{\mathrm{c}, \mathrm{b}+1}}^{\mathrm{gymin}}+\mathrm{l}_{0,0, \mathrm{er}_{\mathrm{c}, 1}}^{\mathrm{gymin}}+\mathrm{l}_{\mathrm{er}_{\mathrm{c}, \mathrm{m}_{\mathrm{x}}-2,0,0}^{\mathrm{gymin}}}^{\mathrm{gym}}\right) \\
\mathrm{C}(\mathrm{t})=\mathrm{C}_{\mathrm{t}}=\frac{1}{\mathrm{v}} *\left[\sum_{\mathrm{c}=1}^{\mathrm{x}}\left(\sum_{\mathrm{b}=1}^{\mathrm{m}_{\mathrm{x}}-2} \mathrm{l}_{\mathrm{er}_{\mathrm{c}, \mathrm{b}}, \mathrm{er}_{\mathrm{c}, \mathrm{b}+1}}^{\mathrm{gymin}}+\mathrm{l}_{0,0, \mathrm{er}_{\mathrm{c}, 1}}^{\mathrm{gymin}_{\mathrm{m}}}+\mathrm{er}_{\mathrm{er}_{\mathrm{c}, \mathrm{m}_{\mathrm{x}}-2,0,0}}^{\mathrm{gymin}}\right)\right]
\end{gathered}
$$

\section{Optimalizálás egy Milkrun útvonalra}

A tényleges minimalizálást a fiktív gyártócsarnokból eredő konkrét számértékek vizsgálatával az Excel Solver és Visual Basic Application programozási nyelv segítségével hajtom végre. Jelen probléma megegyezik a gyakorlatban jól ismert utazóügynök problémával (TSP): olyan minimalizált útvonal létrehozása, amely egy adott pontból indul, és ugyanoda érkezik vissza (jelen feladatban raktári pont), a megadott pontokat (gyártósorok) pontosan egyszer érinti.

Az optimalizálás felírásához a gyártósorok és raktári pont azonosítóit átalakítom számazonosítókká, ugyanis a Solver bővítmény csak ilyen azonosítókkal tud dolgozni. A gyártósor azonosítók mellett szakaszazonosítókat hozunk létre, amelyek tartalmazzák két adott gyártósor közötti távolságot. 
Szakasznak tekinthető két gyártósor közötti útvonal, amelyet legfeljebb elágazás keresztez. A szakaszokhoz tartozó távolságértékek összegzésével kaphatom meg az útvonal hosszát. A leendő minimális útvonalat egy táblázatban írom fel, amely tartalmazza a gyártósor azonosítóját és számazonosítóját, a szakaszazonosítót és a hozzá tartozó értéket, valamint az útvonal is kiolvasható a táblázatból, mivel az egymás alatt lévő gyártósorok adják meg a bejárási sorrendet.

Abban az esetben, ha egymás alatt két olyan gyártósor található, amelyekhez nem írható fel olyan szakasz, hogy legfeljebb elágazás keresztezze, akkor ahhoz a szakaszazonosítóhoz egy irreálisan nagy számot rendeltünk annak érdekében, hogy minimalizálás során ne kerülhessen bele az útvonalba.

\begin{tabular}{|c|c|c|c|}
\hline \multicolumn{4}{|c|}{ MILKRUN ÚTVONAL } \\
\hline GYS azonosítója & GYS számazonosítója & Szakaszazonosító & Szakasz hossza \\
\hline A & 0 & $0-10$ & 10000 \\
\hline GYS10 & 10 & $10-11$ & 2,3 \\
\hline$\ldots$ & $\ldots$ & $\ldots$ & $\ldots$ \\
\hline
\end{tabular}

1. táblázat. Egy Milkrun útvonalra történő optimalizálás eredményét meghatározó táblázat

Az eredményként megkapott útvonal távolsága átszámítva időegységre meghaladja a Milkrun kocsi időkorlátját, így ez a megoldás nem teljesíti az előzetesen felírt korlátozó feltételt.

\section{Milkrun útvonal optimalizálása két járatra}

A metódus ezen szakaszában az adott területet több részre osztjuk fel, majd minden kapott területhez meghatározzuk a legrövidebb útvonalat az utazóügynök probléma segítségével. Az ilyen feladatokat a szakirodalom mTSP (Multiple Travelling Salesman Problem) néven említi. A módszer első lépése a legrövidebb útvonal meghatározása minden gyártósorhoz. Ennek a végrehajtását szintén az Excel Solver bővítményével hajtjuk végre. Minden szakaszazonosítóhoz rendelünk egy bináris értéket, amely megadja, hogy az adott szakasz részese-e az útvonalnak. Azok a szakaszok, amelyek az útvonal részei „1" értéket, amelyek nem részei, „0" értéket kapnak. Így ha ezt a bináris értéket megszorozzuk a szakasz hosszával, majd összegezzük azokat, megkapjuk az útvonal hosszát (valójában azok a szakaszok, melyek az útvonalak részei kerülnek összeadásra). A Solver ezeket a bináris értékeket választja ki úgy, hogy az útvonal hossza minimális legyen. A korlátozó feltételeket a gyártósorok kezdő és végpontja adja meg, így lehet tetszőlegesen bármelyik gyártósorra meghatározni a minimális útvonalat.

Miután minden gyártósorra meghatároztuk a legrövidebb útvonalat, vizsgálhatjuk azok szakaszaszegyezéseit. Két gyártósor között annál szorosabb a kapcsolat, minél több szakaszegyezéseik vannak. Ezeket az adott gyártósorok bináris táblázatával tudjuk megvizsgálni, egyezésnek tekinthető, ha két gyártósor egy szakaszhoz tartozó bináris értéke megegyezik. Ez elvégezhető az összes gyártósorpárra.

Az optimalizálás harmadik lépéseként a gyártósor-párokból gyártósor csoportokat képezhetünk annak érdekében, hogy leredukáljuk a gyártósorok számát. A csoportokot a gyártósor-párok összefüzésével hozzuk létre, pl. ha a GYS1-GYS2, illetve GYS2-GYS3 párokat társítjuk, akkor a csoportot a GYS1, GYS2, GYS3 alkotják. Minden párhoz tartozik egy arányszám, amely a szakaszegyezések számát és a legrövidebb útvonalak összegét viszonyítja egymáshoz. Azokból a párokból képzünk csoportokat, amelyek megfelelnek az arányszám korlátozásnak.

A módszer utolsó lépéseként az első három lépés ismétlődik, ezúttal nem gyártósorokkal, hanem gyártósor csoportokkal számolva. Minden csoporthoz meghatározható a legrövidebb útvonal, majd vizsgálhatók a csoportok szakaszegyezései, végül újabb nagyobb csoportokat képezhetünk. 
Az arányszám alsó és felső kritériumát úgy választjuk meg, hogy pontosan annyi csoport alakuljon ki, ahány útvonalra szeretnénk elvégezni a feladatot. A konkrét példában $2 \mathrm{db}$ útvonalra zajlik a minimalizálás, de elvégezhető $\mathrm{n}$ db útvonalra is. Miután a gyártósor területe fel lett osztva, végrehajtható az optimalizálás ugyanazzal a módszerrel (TSP), mint egy útvonalra történő optimalizálás esetén.

A kapott időeredmény megfelel az eredeti időkorlátozásnak, így a feladat megoldottnak tekinthető. Abban az esetben, ha az eredmény nem felel meg a korlátozásnak, a területet újból fel kell osztani az előbb leírt módszerrel figyelve arra, hogy a területek száma nem haladhatja meg a rendelkezésre álló kocsik számát.

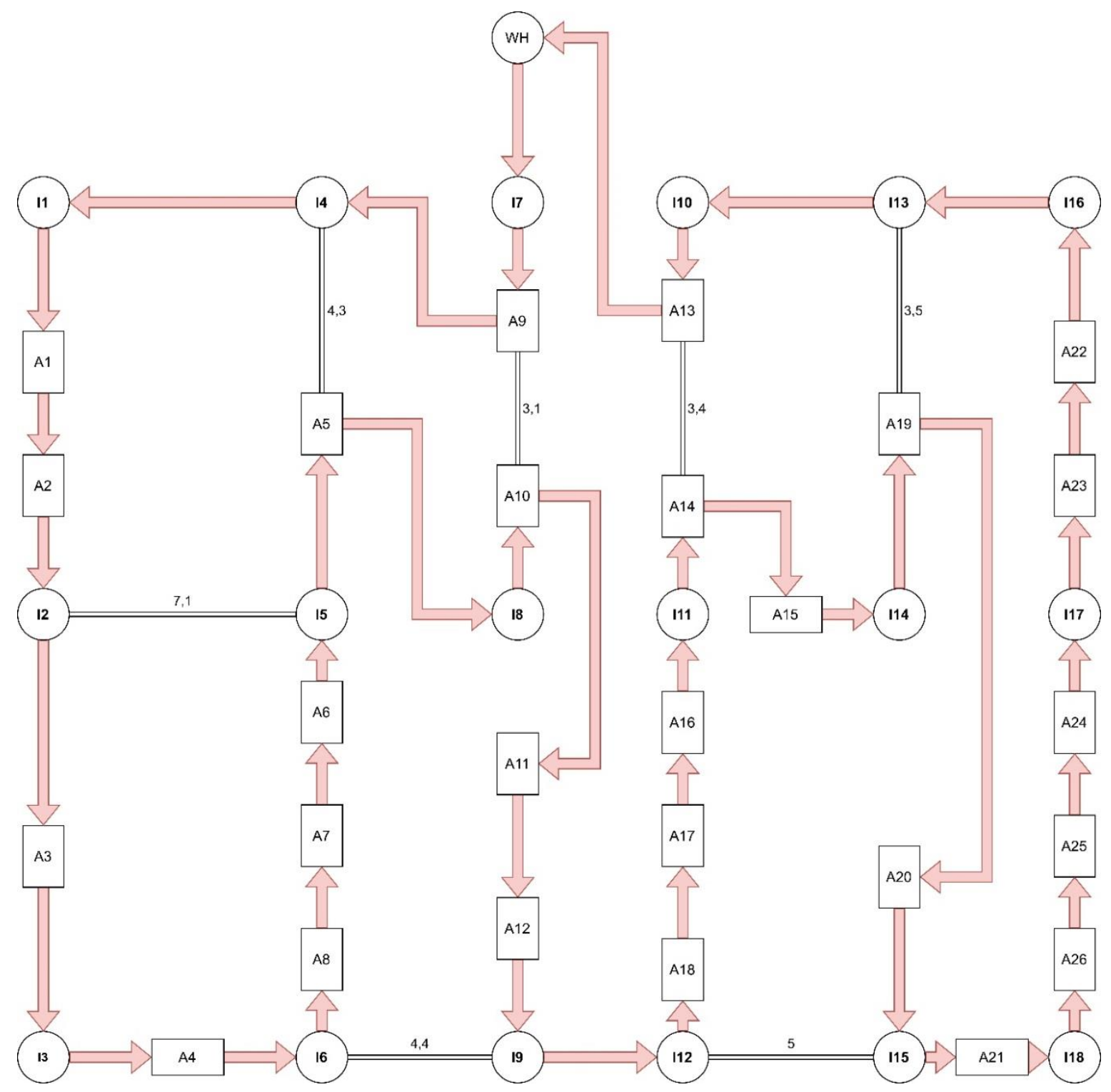

2. ábra. Egy Milkrun útvonalra történö minimalizálás eredménye 


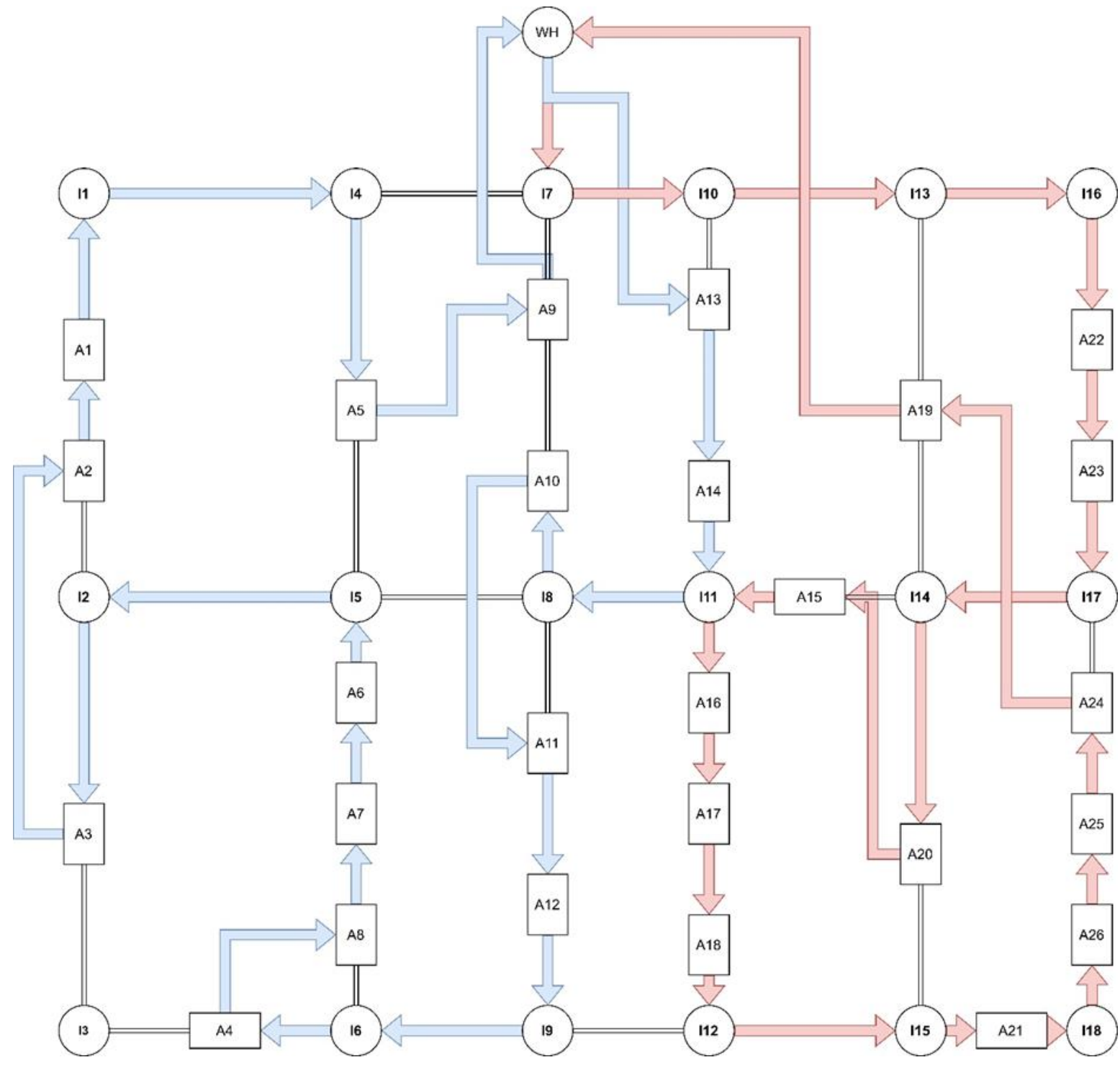

3. ábra. Az optimalizálás eredményeként létrejött Milkrun útvonalak

\section{7. Összefoglalás}

Minden autóipari vállalatnak célja a termelésen belüli átfutási idő csökkentése. Jelen tudományos cikk célja egy olyan algoritmus létrehozása volt, amely az alapanyagellátásért, illetve késztermék felvételért felelős Milkrun kocsik útvonalait minimalizálja. A metódus két részre bontható: egy Milkrun kocsival történő anyagellátáshoz a logisztikai optimalizálásban már népszerünek tekinthető utazóügynök módszert (TSP), több Milkrun kocsival történő anyagellátáshoz pedig a jelenlegi feladathoz egyedileg készített metódust használtuk. A módszer lényege, hogy gyártósor csoportokat képezzünk, amivel leredukáljuk a gyártósorok számát, ameddig annyi csoport képződik, amennyi kocsira szeretnénk optimalizálni a gyártócsarnokot. A feladat megoldásához a Microsoft Excel szoftvert használtuk, illetve annak Solver bővítményét az optimalizáláshoz, valamint VBA programozási nyelvet a bonyolultabb függvények megoldásához. Kutatásunk következő célja a módszert kiterjeszteni az 
autóiparban is használt gyártócsarnok méretekre, alkalmazni a konkrét fizikális gyakorlatban. Ezen felül további célunk - az út és idő paraméteren túl - a gyártósorok alapanyagigényének és késztermék elszállítási igényének figyelembevétele az optimalizált útvonalak létrehozásakor.

\section{Köszönetnyilvánítás}

A cikkben ismertetett kutató munka az EFOP-3.6.1-16-2016-00011 jelü „Fiatalodó és Megújuló Egyetem - Innovatív Tudásváros - a Miskolci Egyetem intelligens szakosodást szolgáló intézményi fejlesztése" projekt részeként - a Széchenyi 2020 keretében - az Európai Unió támogatásával, az Európai Szociális Alap társfinanszírozásával valósul meg.

\section{Irodalom}

[1] Wiegel, F., Immler, S., Knobloch, D., Abele, E.: Simulation-based optimization of internal Milkruns: Development of a simulation model for planning and optimizing the provision of material. Productivity Management 2013,18(1):51-54.

[2] Saysaman, A., Chutima, P.: Transportation of part supply improvement in agricultural machinery assembly plant. IOP Conference Series: Materials Science and Engineering 2018, 311(1):012010. https://doi.org/10.1088/1757-899X/311/1/012010

[3] Lieb, C., Hormes, F., Günthner, W.A., Fottner, J.: Modelling and analysis of the demand volatility in in-plant milkruns serving scheduled mixed-model production facilities. Logistics Journal 2018:1-16. https://doi.org/10.2195/lj_Proc_lieb_de_201811_01

[4] Martini, A., Stache, U., Trenker, F.: Planning of internal milkrun systems - Overview of possible design alternatives and comparison of planning methods. ZWF Zeitschrift fuer Wirtschaftlichen Fabrikbetrieb 2014, 109(1-2):50-55. https://doi.org/10.3139/104.111086

[5] Hormes, F., Lieb, C., Fottner, J., Günthner, W.A.: In-plant Milkrun control-morphological classification of static und dynamic approaches. ZWF Zeitschrift fuer Wirtschaftlichen Fabrikbetrieb 2017, 112(11): 778-782. https://doi.org/10.3139/104.111821

[6] Kholil, M., Hendri, David Mangaraja, R., Bagus Yosan, R.: Improving the efficiency of the milkrun truck suppliers in cikarang area by merging the payload cycles and optimizing the milkrun route using the saving matrix methods. Journal of Physics: Conference Series 2019, 1175(1):012201. https://doi.org/10.1088/1742-6596/1175/1/012201

[7] Bocewicz, G., Bozejko, W., Wójcik, R., Banaszak, Z.: Milk-run routing and scheduling subject to a trade-off between vehicle fleet size and storage capacity. Management and Production Engineering Review 2019, 10(3):41-53. https://doi.org/10.24425/mper.2019.129597

[8] Pawlewski, P.: Interactive layout in the redesign of intralogistics systems. Advances in Intelligent Systems and Computing 2019, 835:462-473. https://doi.org/10.1007/978-3-319-97490-3_45

[9] Bányai, T., Telek, P., Landschützer, C.: Milkrun based in-plant supply - An automotive approach. Lecture Notes in Mechanical Engineering 2018:170-185. https://doi.org/10.1007/978-3-319-75677-6_14

[10] Teschemacher, U., Reinhart, G.: Ant Colony Optimization Algorithms to Enable Dynamic Milkrun Logistics. Procedia CIRP 2017, 63:762-767. https://doi.org/10.1016/j.procir.2017.03.125

[11] Droste, M., Hasselmann, V.-R., Deuse, J.: Optimization of in-plant milkrun systems: Development of a parameter-based model to optimize the provision of materials. Productivity Management 2012, 17(1):25-28.

[12] Kovács, A.: Optimizing the storage assignment in a warehouse served by milkrun logistics. International Journal of Production Economics 2011, 133(1):312-318. https://doi.org/10.1016/j.ijpe.2009.10.028 
[13] Vieira, A., Dias, L.S., Pereira, G.B., Oliveira, J.A., Carvalho, M.S., Martins, P.: 3D micro simulation of milkruns and pickers in warehouses using Simio. Modelling and Simulation 2014 European Simulation and Modelling Conference, pp. 261-269.

[14] Fedorko, G., Vasil, M., Bartosova, M.: Use of simulation model for measurement of MilkRun system performance. Open Engineering 2019, 9(1):600-605. https://doi.org/10.1515/eng-2019-0067

[15] Pokorádi, L.: Mi is az a matematikai modell. debreceni Szemle, 2002, 11:1-14. 